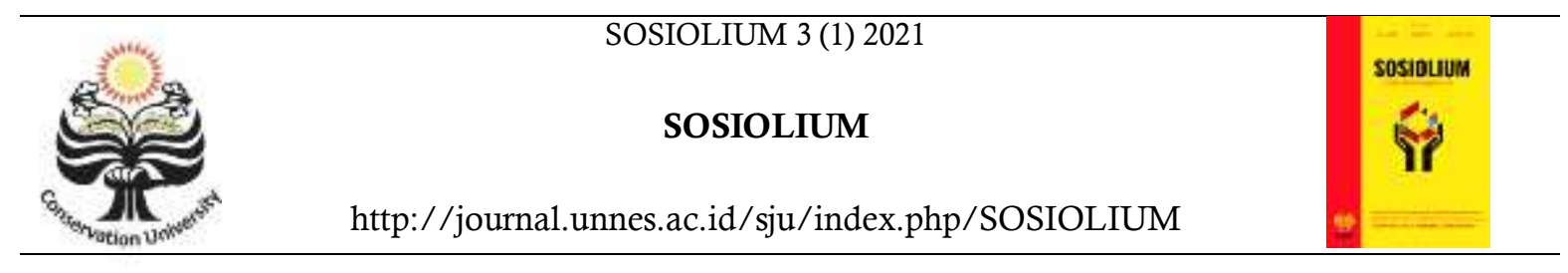

\title{
PEMANFAATAN SUMBER BELAJAR IPS DALAM PROSES PEMBELAJARAN DARING DI MTS S SULTAN AGUNG SRATI
}

\author{
Nurul Army Ocatviani, Ferani Mulianingsih ${ }^{\bowtie}$ \\ Prodi Pendidikan Ilmu Pengetahuan Sosial, Fakultas Ilmu Sosial, Universitas Negeri Semarang, Indonesia
}

\section{Info Artikel}

SejarahArtikel:

Disubmit: Januari 2021

Direvisi: Februari 2021

Diterima: Maret 2021

\section{Keywords:}

Social Studies

Learning Resources,

Online Learning

\begin{abstract}
Abstrak
Pembelajaran berbasis potensi daerah tercermin dalam peraturan pemerintah dalam kurikulum 2013, dimana peserta didik harus mampu mengaitkan pengetahuan dengan seluruh aspek kehidupan. Penelitian ini menggunakan metode penelitian kualitatif. Teknik pengumpulan data melalui observasi, wawancara, dan dokumentasi. Sumber data diperoleh dari sumber data primer dan sekunder. Uji validitas dalam penelitian menggunakan triangulasi dan teknik analisis data terdiri dari pengumpulan data, reduksi data, penyajian data dan penarikan simpulan. Hasil penelitian menunjukkan bahwa proses pembelajaran dilakukan secara daring berpedoman pada kurikulum darurat dan penggunaan rencana pelaksanaan pembelajaran satu lembar akibat dari adanya pandemic covid-19. Dalam pelaksanaan pembelajaran guru memanfaatkan buku paket IPS dan buklet pariwisata Pantai Menganti sebagai sumber belajar IPS. Fokus materi dalam penelitian ini adalah materi sumber daya alam dan kemaritiman. Adapun output dari pembelajaran tersebut berupa rangkuman materi potensi sumber daya alam dan kemaritiman. Kendala yang ditemukan adalah minimnya sumber belajar, terbatasanya media pembelajaran dan jaringan internet.
\end{abstract}

\begin{abstract}
Region potential based learning is reflected goverment regulations in the 2013 curriculum, where students must be able to link knowledge with all aspects of life. This study used qualitative research methods. Data collections tecniques throught observation interviews, and documentation. Data sources were obtained from primary and secondary data sources. The validity test in the study used triangulation and data analysis techniques consisted of data collection, data reduction, data presentation and drawing conclusions. The results showed that the learning implementation plan as a result of the covid-19 pandemic. In implementating the learning proces the teacher use the social studies package book and the Menganti Beach tourism booklet as a social science learning resources. The focus of the material in this research is natural resources and maritime materials. The output of the learning is the from of a summary of the material potential of natural and maritime resources. The obstacles found were the lack of learning resources, limited learning media and internet networks.
\end{abstract}

\footnotetext{
${ }^{\bowtie}$ Alamat korespondensi:

E-ISSN 2685-4929

Gedung C1, Lantai 1, FIS UNNES

Kampus Sekaran, Gunungpati, Semarang, 50229

Email: feranigeographer@mail.unnes.ac.id
} 


\section{PENDAHULUAN}

Pendidikan merupakan salah satu upaya untuk mewujudkan amanat pembukaan UUD 1945, yaitu memajukan kesejahteraan umum dan mencerdaskan kehidupan bangsa serta ikut melaksanakan ketertiban dunia. Dalam Undang-Undang Sistem Pendidikan Nasional No 20 Tahun 2003 dijelaskan bahwa pendidikan merupakan sebuah usaha sadar dan terencana untuk mewujudkan suasana belajar dan proses pembelajaran sedemikian rupa supaya peserta didik dapat mengembangkan potensi dirinya secara aktif supaya memiliki pengendalian diri, kecerdasan, keterampilan dalam bermasyarakat, kekuatan spiritual keagamaan, kepribadian serta akhlak mulia. Salah satunya adalah melalui pembelajaran IPS (Ilmu Pengetahuan Sosial).

IPS merupakan salah satu bahan kajian yang wajib dimuat dalam kurikulum pendidikan dasar dan menengah yang mencakup ilmu bumi, sejarah, ekonomi, kesehatan yang dimaksudkan untuk mengembangkan pengetahuan, pemahaman, dan kemampuan analisis peserta didik terhadap kondisi sosial masyarakat (UU Sisdiknas 2003:19). Pada konteks di Indonesia IPS merupakan sebuah gabungan dari berbagai disiplin ilmu sosial yang mengalami penyederhanaan sesuai tingkat pendidikan (Mulianingsih, 2017:60). MTs S Sultan Agung Srati merupakan salah satu sekolah menengah pertama yang berada di Kecamatan Ayah Kabupaten Kebumen. MTs S Sultan Agung Srati letaknya jauh dari pusat kota, tepatnya \pm $16 \mathrm{Km}$ dari pusat kecamatan dan $\pm 38 \mathrm{Km}$ dari pusat kabupaten.

Berdasarkan hasil observasi dengan Ibu Siti Ludiyah (guru mata pelajaran IPS) pada tanggal 3 Maret 2020 sumber belajar yang terbatas disekolah salah satunya disebabkan oleh homogenitas lingkungan hidup peserta didik, kemudahan segala akses antar peserta didik mengakses internet maupun sumber belajar lain seperti buku untuk lebih sulit didapatkan karena jaraknya yang jauh dari pusat kota baik kecamatan maupun kabupaten. Bapak Gatot (guru MTs dan Pembina MTs S Sultan Agung Srati) menjelaskan belum ada variasi sumber belajar juga berkaitan dengan fasilitas sekolah yang sangat minim, di sekolah sendiri hanya terdapat 3 komputer yang digunakan untuk praktik peserta didik, 1 printer, $2 \mathrm{LCD}, 2$ alat audio visual yang seluruhnya merupakan gabungan milik MA dan MTs S Sultan Agug Srati.

Proses pembelajaran disekolah pada saat ini dilakukan secara daring (dalam jaringan) yang diakibatkan dari adanya pandemi virus corona di Indonesia. Kabupaten Kebumen merupakan salah satu kabupaten yang telah menerapkan kurikulum darurat untuk proses pembelajaran. Kurikulum tersebut merujuk pada keputusan Direktur Jenderal Pendidikan Islam No 1972. Pembelajaran secara daring membutuhkan adanya media/alat untuk menunjang pembelajaran tersebut seperti HP atau laptop untuk melaksanakan proses pembelajaran.

Berdasarkan hasil observasi dapat disimpulkan bahwa permasalahanpermasalahan yang terdapat di MTs S Sultan Agung Srati berpusat pada sarana dan prasarana sekolah terkait pembelajaran didalam kelas terutama pada sarana dan sumber belajar yang digunakan oleh sekolah untuk menunjang pembelajaran secara daring. Sumber belajar adalah sesuau yang dapat mengandung pesan untuk disajikan melalui alat ataupun oleh dirinya sendiri dapat pula merupakan sesuatu yang digunakan untuk menyampaikan pesan yang tersimpang dalam bahan pembelajaran yang akan diberikan (Hafid, 2011). Keterbatasan sekolah terkait sumber belajar dan sarana prasarana yang digunakan dalam kegiatan pembelajaran daring di MTs S Sultan Agung Srati menjadi salah satu faktor kurangnya sumber belajar.

Minimnya variasi sumber belajar oleh guru serta adanya himbauan untuk pembelajaran yang dilakukan secara daring menyebabkan proses pembelajaran IPS berjalan kurang optimal. Berdasarkan analisis permasalahan di atas, maka peneliti tertarik untuk meneliti permasalahan tersebut dengan judul "Pemanfaatan Sumber Belajar IPS Dalam Pembelajaran Daring di MTs S Sultan Agung Srati Kabupaten Kebumen". Penelitian ini berfokus pada 1) Pemanfaatan sumber 
belajar yang digunakan dalam proses pembelajaran IPS di MTs S Sultan Agung Srati; 2) kendala yang dialami selama proses pembelajaran IPS daring; dan 3) upaya perbaikan yang dilakukan guru dalam proses pembelajarn IPS secara daring.

\section{METODE}

Penelitian ini menggunakan metode penelitian kualitatif.Metode penelitian kualitatif ini digunakan sebagai prosedur penelitian yang menghasilkan data deskriptif berupa kata-kata tertulis atau lisan dari orang-orang yang diamati.Krik dan Miller mendefinisikan bahwa penelitian kualitatif adalah tradisi dalam ilmu pengetahuan sosial yang secara fundamental bergantung pada pengamatan manusia dalam kawasan sendiri dan berhubungan dengan orang-orang tersebut (Nugrahani, 2014:8). Penelitian ini merupakan penelitian deksriptif kualitatif yang ditunjuk untuk mendeskripsikan dan menunjukan gambar dari fenomena yang ada, baik bersifat alamiah maupun rekayasa dari manusia.

Fokus penelitian disini adalah bagaimana pemanfaatan sumber belajar IPS yang digunakan pada masa pembelajaran yang dilakukan secara daring. Lokasi penelitian ini MTs S Sultan Agung Srati, tepatnya berada di Desa Srati, Kecamatan Ayah, Kabupaten Kebumen. Subjek yang akan diteliti dalam penelitian ini adalah Kepala Sekolah, Guru IPS, Wakil Kurikulum, dan peserta didik kelas VII di MTs S Sultan Agung Srati. Sumber data dalam penelitian ini diperoleh melalui data primer dan skunder. Data primer diperoleh melalui observasi dan wawancara, sedankan data sekunder berasal dari dokumentasi berupa foto kegiatan pembeajaran dan dokumen berupa buku, jurnal ataupun artikel yang berkaitan. Uji validitas data yang digunakan dalam penelitian ini adalah dua triangulasi yakni triangulasi sumber dan teknik. Uji keabsahan data yang digunakan dalam penelitian ini adalah model interaktif Miles Huberman berupa pengumpulan data, reduksi data, penyajian data, dan penarikan kesimpulan atau verifikasi.

\section{HASIL DAN PEMBAHASAN}

\section{Pemanfaatan Sumber belajar IPS dalam Proses Pembelajaran Daring di MTs S Sultan Agung Srati}

Pada prakteknya terdapat dua jenis sumber belajar yang dimanfaatkan oleh sekolah untuk mendukung proses pembelajaran IPS yang dilakukan secara daring. Sumber belajar tersebut yaitu guru, dan buku yang berupa paket IPS dan buklet pariwisata Pantai Menganti. Buku paket IPS dan buklet pariwisata Pantai Menganti merupakan sumber belajar utama dan sumber belajar pendukung di MTs S Sultan Agung Srati. Adapun sumber belajar pendukung berupa buklet pariwisata digunakan dalam materi sumber daya alam dan kemaritiman. Pada proses pelaksanaannya terdapat beberapa tahapan diantaranya sebagai berikut:

\section{a. Perencanaan Pembelajaran IPS}

Perencanaan digunakan pada tahap awal sebelum guru masuk kedalam kelas untuk melaksanakan proses pembelajaran, dalam prosesnya perencanaan menyangkut pembuatan program tahunan, program semester, penyusunan silabus, dan RPP (Rencanaan Perangkat Pembelajaran).

b. Pelaksanaan Pembelajaran IPS

Pelaksanaan pembelajaran IPS memerlukan beberapa poin untuk menunjang sebuah proses pembelajaran terjadi. Beberapa poin tersebut diantaranya 1) Sumber belajar, berdasarkan hasil penelitian dan observasi peneliti dapat diketahui bahwa sumber belajar yang digunakan oleh kelas VII MTs S Sultan Agung Srati berupa guru, buku paket IPS, dan buklet pariwisata; 2) Media pembelajaran, hasil penelitian menyebutkan bahwa media pembelajaran yang digunakan di sekolah ini adalah HP atau alat elektronik sejenisnya melalui whatsapp; 3) Metode pembelajaran, Hasil penelitian dan observasi, dapat diketahui bahwa selama pembelajaran 
daring, tidak ada metode khusus yang digunakan guru. Menggunakan kurikulum darurat, dimana RPP merupakan RPP satu lembar yang didalamnya tidak terdapat indikator metode pembelajaran. Pembelajaran tatap muka hanya dilakukan untuk memberikan tugas dan mengumpulkan tugas.

c. Evaluasi Pembelajaran

Berdasarkan hasil penelitian dapat diketahui bahwa ditengah kondisi pembelajaran yang dilakukan secara daring, evaluasi tidak dapat dilakukan seperti cara semestinya seperti melakukan tes lisan maupun tes tertulis.

2. Kendala dalam proses pembelajaran IPS secara daring di MTs S Sultan Agung Srati Oemar hamalik (2010:16) menjelaskan bahwa kendala dalam belajar merupakan beberapa hambatan yang menghalangi jalannya pembelajaran yang dilihat dari faktor manusiawi (guru dan peserta didik). Berdasarkan hasil penelitian terdapat kendala atau penghambat dalam proses pelaksanaannya diantaranya adalah terletak pada fasilitas dan keadaan dimana fasilitas peserta didik terkait media pembelajaran masih sangat minim serta keadaan daring yang memaksa peserta didik tetap menggunakan media tersebut.

\section{Upaya Perbaikan dalam Proses Pembelajaran IPS SecaraDaring di MTs S Sultan Agung Srati}

Berdasarkan hasil penelitian dapat diketahui bahwa upaya perbaikan yang dilakukan guru dalam pembelajaran IPS secara daring dilakukan dengan melalukan perbaikan pada permasalahan yang dihadapi guru selama proses pembelajaran baik itu kendala eksternal maupun kendala internal. Upaya guru dalam melakukan perbaikan permasalahan eksternal dengan cara a) menetapkan jadwal tetap yang mewajibkan peserta didik sekali disetiap minggunya untuk hadir ke sekolah mengambil dan mengumpulkan tugas baru; b) memberikan sumber belajar tambahan seperti modul, diktat, dan sebagainya; c) mengenalkan aplikasi ataupun link buku. Sedangkan terkait permasalahan internal dilakukan dengan cara 1) meningkatkan inovasi guru dengan mengunakan teknik dalam pembelajaran daring seperti teknik merangkum sebagai salah satu upaya memancing pemahaman peserta didik terhadap materi yang diberikan, meskipun tidak semua materi dapat diberlakukan demikian. 2) guru juga melakukan bimbingan melalui grup untuk peserta didik yang merasa sulit memahami materi pembelajaran.

\section{SIMPULAN}

Berdasarkan hasil penelitian Pemanfaatan Sumber Belajar IPS dalam proses pembelajaran daring di MTs S Sultan Agung Srati dapat disimpulkan bahwa sumber belajar IPS yang digunakan terdiri dari dua jenis yaitu guru dan buku. Guru merupakan fasilitator utama yang memberikan pemahaman serta pembelajaran kepada peserta didik dengan bantuan sumber belajar lain berupa buku paket IPS dan buklet pariwisata Pantai Menganti.

Selama proses pelaksanaan pembelajaran, terdapat beberapa kendala yang disebabkan baik oleh factor internal maupun eksternal. Dari factor internal kendala terjadi disebabkan oleh pemahaman dari setiap peserta didik yang berbeda dalam hal menangkap materi pembelajaran sehingga dibutuhkan adanya inovasi dari guru untuk membuat peserta didik mampu menangkap pembelajaran dengan lebih baik. Kendala dari factor eksternal disebabkan oleh sarana dan prasarana baik dari sekolah maupun peserta didik yang terbatas.

\section{DAFTAR PUSTAKA}

Hafid. 2011. 'Sumber dan Media Pembelajaran'. Sulesana Vol. 6. No. 2. Hal. 70.

Hamalik, Oemar. 2010. Proses Belajar Mengajar. Jakarta : PT Bumi Aksara. 
Hanapi, D. 2016. 'Pemanfaatan Objek Pariwisata Sebagai Sumber Belajar Kontekstual'. Vol. 1. No. 1. Hal. 1.

Mulianingsih, Ferani. 2017. 'Fenomena Rob Semarang Sebagai Sumber Belajar IPS'. Jurnal Harmony. Vol. 2 No. 1.Hal.59-64.

Nugrahani, Farida. 2014. Metode Penelitian Kualitatif dalam Penelitian Pendidikan Bahasa.Surakarta.

Undang-undang Nomor 20 Tahun 2003 Tentang Sistem Pendidikan Nasional pasal 3 